\title{
Theoretical Estimate of the Effective Recombination Coefficient in the $D$ Region
}

\author{
Hiroshi KAMIYAMA \\ Geophysical Institute, Tohoku University, \\ Sendai, Japan
}

(Received September 25, 1971)

\begin{abstract}
In the presence of a large number of positive and negative ionic species, an analytical expression for the effective recombination coefficient of electrons in the $D$ region is derived in the same from, $a^{\prime}=\left\langle\alpha_{e}\right\rangle$ $+\lambda\left\langle\alpha_{\text {ion }}\right\rangle$, as is customarily used in the upper regions. Here, $\left\langle\alpha_{e}\right\rangle$ is the electronic recombination coefficient averaged with weights proportional to the abundance of various kinds of positive ions, and $\left\langle\alpha_{\text {ion }}\right\rangle$ is the weighted mean of the various ionic recombination coefficients according to the composition of positive and negative ions. The effective loss rate of electrons are given as $(1+\lambda) \alpha^{\prime}$ in which the negative ion-electron ratio $\lambda$ changes in a wide range as a function of altitude. Under the assumption of a model atmosphere containing eight minor constituents, this paper calculates the density distributions of thirteen species of positive ions and seven species of negative ions as well as of electrons. Based on the result, the effective recombination coefficient is estimated to be $4.2 \times 10^{-7} \mathrm{~cm}^{3} \mathrm{sec}^{-1}$ at the $80 \mathrm{~km}$-level, $1.5 \times 10^{-6} \mathrm{~cm}^{3} \mathrm{sec}^{-1}$ at $70 \mathrm{~km}$, and $1.9 \times 10^{-5} \mathrm{~cm}^{3} \mathrm{sec}^{-1}$ at $60 \mathrm{~km}$, while $\lambda$ increases rapidly with decreasing height, being about $5.3 \times 10^{-3}$ at $80 \mathrm{~km}, 7.9 \times 10^{-1}$ at $70 \mathrm{~km}$, and $1.0 \times 10^{-1}$ at $60 \mathrm{~km}$ in a daytime condition. The effective loss rate estimated in this paper is shown to be consistent with the results derived from observations of solar eclipse, SID, and PCA events.
\end{abstract}

\section{Introduction}

The $D$ region of the ionosphere has long been thought of as the region in which an anomalous increase in ionization due to the solar flare X-ray or impinging particles causes SID or PCA events. Because of the relatively low electron density in the region concerned, however, only indicative information had been inferred from the propagation of radio waves until electron density and ion composition began to be measured directly by means of rockets in recent years. Based on the electron density profiles measured by Mechtly and Smith (1968), Sechrist (1968) suggested that 
negative ions, such as $\mathrm{CO}_{3}{ }^{-}$and $\mathrm{NO}_{3}{ }^{-}$having high electron affinities, play an important role in the $D$ region. NARCISI and BAILEY (1965) detected a considerable amount of positive ions of mass 19 and 37 which were interpreted as water cluster ions, and FEHSENFELD and FERGUSON (1969) discussed the chemical processes leading to the formation of such ions as $\mathrm{H}_{3} \mathrm{O}^{+}, \mathrm{H}_{3} \mathrm{O}^{+}\left(\mathrm{H}_{2} \mathrm{O}\right)$, and $\mathrm{H}_{3} \mathrm{O}^{+}\left(\mathrm{H}_{2} \mathrm{O}\right)_{2}$.

This paper describes in the following section an analytical expression for the effective recombination coefficient of electrons in the $D$ region in the presence of a large number of positive and negative ion species. To estimate the height distribution of the coefficient, the ion composition is calculated tentatively as a function of altitude employing a model atmosphere. From the comparison of the theoretical distribution of the water cluster ions with the observed result, a brief discussion is given on the amount of water vapor in the mesosphere.

\section{Effective Recombination Coefficient}

Electrons are produced through photoionization of some of atmospheric constituents by solar UV radiation and X-ray and through impact ionization of all of the constituents by impinging cosmic rays. Electrons are also created through photodetachment by solar radiation and through collisions by neutral particles from negative ions. On the other hand, electrons are lost by recombination with positive ions and by attachment to neutral particles. Then, the electron density $n_{e}$ is given by

$$
\frac{d n_{e}}{d t}=\sum_{x} q_{x}-n_{e} \sum_{i}\left(\alpha_{e i} n_{i}^{+}\right)-n_{e} \sum_{j} \sum_{x}\left(\beta_{j x} n_{x}\right)+\sum_{j} \sum_{x}\left(\gamma_{x j} n_{x} n_{j}^{-}\right)+\sum_{j}\left(\mu_{j} n_{j}^{-}\right),
$$

where $q_{x}$ is the rate of electron production from the $x$-th component of neutral gases, $\alpha_{e i}$ the electronic recombination coefficient with positive ions of the $i$-th species whose number density is $n_{i}^{+}, \beta_{j x}$ the rate coefficient for an attachment process in which a negative ion of the $j$-th kind is produced through the collision of an electron with a neutral particle of the $x$-th component whose density is $n_{x}, \gamma_{x j}$ the coefficient of collisional detachment from negative ions of the $j$-th species whose density is $n_{j}^{-}$due to the collision of a neutral particle of the $x$-th kind, and $\mu_{j}$ the photodetachment coefficient for negative ions of the $j$-th species.

Negative ions of the $j$-th kind are produced through attachment processes, and are lost by detachment of electrons and by recombination with positive ions. In addition, the number density of the $j$-th negative ions increases and decreases due to charge transfer processes at the rates, $P_{j}$ and $L_{j}$, respectively. Then, the $j$-th negative ion density is given by 


$$
\frac{d n_{j}^{-}}{d t}=n_{e} \sum_{x} \beta_{j x} n_{x}-\sum_{x}\left(\gamma_{x j} n_{x} n_{j}^{-}\right)-\mu_{j} n_{j}^{-}-n_{j}^{-} \sum_{i}\left(\alpha_{i j} n_{i}^{+}\right)+P_{j}-L_{j}
$$

where $\alpha_{i j}$ is the coefficient for ionic recombination and mutual neutralization between a negative ion of the $j$-th kind and a positive ion of the $i$-th species. Since the charge transfer processes as a whole follow $\sum_{j} P_{j}=\sum_{j} L_{j}$, one obtains

$$
\frac{d n^{-}}{d t}=n_{e} \sum_{j} \sum_{x}\left(\beta_{j x} n_{x}\right)-\sum_{j} \sum_{x}\left(\gamma_{x j} n_{x} n_{j}^{-}\right)-\sum_{j}\left(\mu_{j} n_{j}^{-}\right)-\sum_{j} \sum_{i}\left(\alpha_{i j} n_{i}^{+} n_{j}^{-}\right)
$$

where $n^{-}$denotes the total density of negative ions.

Putting $n^{-}=2 n_{e}$ and assuming the charge neutrality, the addition of Eqs. (1) and (3) gives

$$
\frac{d}{d t}(1+\lambda) n_{e}=\sum_{x} q_{x}-n_{e} \sum_{i}\left(\alpha_{e i} n_{i}^{+}\right)-\sum_{j} \sum_{i}\left(\alpha_{i j} n_{i}^{+} n_{j}^{-}\right) \text {. }
$$

If the weighted means of the recombination coefficients given by

$$
\begin{aligned}
& <\alpha_{e}>=\frac{\sum_{i}\left(\alpha_{e i} n_{i}^{+}\right)}{\sum_{i} n_{i}^{+}}, \\
& <\alpha_{j}>=\frac{\sum_{i \cdot}\left(\alpha_{i j} n_{i}^{+}\right)}{\sum_{i} n_{i}^{+}},
\end{aligned}
$$

and

$$
<\alpha_{\text {ion }}>=\frac{\sum_{j}\left(<\alpha_{j}>n_{j}^{-}\right)}{\sum_{j} n_{j}^{-}}
$$

are employed,

$$
\frac{d}{d t}(1+\lambda) n_{e}=\sum_{x} q_{x}-(1+\lambda)\left(<\alpha_{e}>+\lambda<\alpha_{\text {ion }}>\right) n_{e}^{2} .
$$

When the change in the negative ion-electron ratio can be ignored, one obtains a recombination type expression;

$$
\frac{d n_{e}}{d t}=q^{\prime}-\alpha^{\prime} n_{e}^{2},
$$

where $q^{\prime}$ is the effective rate of electron production and is given by

$$
q^{\prime}=\frac{\sum_{x} q_{x}}{1+\lambda},
$$

and $\alpha^{\prime}$ is the effective recombination coefficient given by

$$
\left.\alpha^{\prime}=\left\langle\alpha_{e}\right\rangle+\lambda<\alpha_{\text {ion }}\right\rangle .
$$

Hence, the effective loss rate $\phi$ is defined as

$$
\phi=\frac{\sum_{x} q_{x}}{n_{e}^{2}}=(1+\lambda) \alpha^{\prime}
$$


As shown above, the recombination coefficient is given by an expression in the same form as is customarily used for the upper region of the ionosphere. Here, the electronic recombination coefficients should be averaged with weights according to the compasition of positive ions, and the ionic recombination coefficients should be averaged first with weights proportional to the abundance of positive ions and then with weights proportional to the negative ion abundance. Thus, in estimating the effective loss rate for electrons in the $D$ region, the ion composition and the negative ion-electron ratio $\lambda$ are required to be known as functions of altitude.

\section{A Calculated Model for the $D$ Region}

The atmospheric region concerned is characterized by the existence of many kinds of minor constituents resulting from photodissociation of atmospheric molecules. The distribution of such minor constituents has been studied by a number of authors, but the discrepancies between theory and observation have not yet been removed completely. To make a tentative estimate of the effective recombination coefficients, this paper assumes the distribution of minor constituents as shown in Fig. 1. The theoretical results are adopted from HunT (1966) for $\mathrm{H}_{2} \mathrm{O}$ and $\mathrm{OH}$, from ShimAZAKI and LAIRD (1970) for O, and from HesstvedT and JANson (1969) for $\mathrm{N}, \mathrm{NO}$, and $\mathrm{NO}_{2}$. The distribution of $\mathrm{O}_{3}$ is based on the result obtained from rocket observations (SMiTH, 1969). Since the assumption made above will introduce some ambiguity in the result, the effect of a change in the amount of each of the constituents will be discussed in full

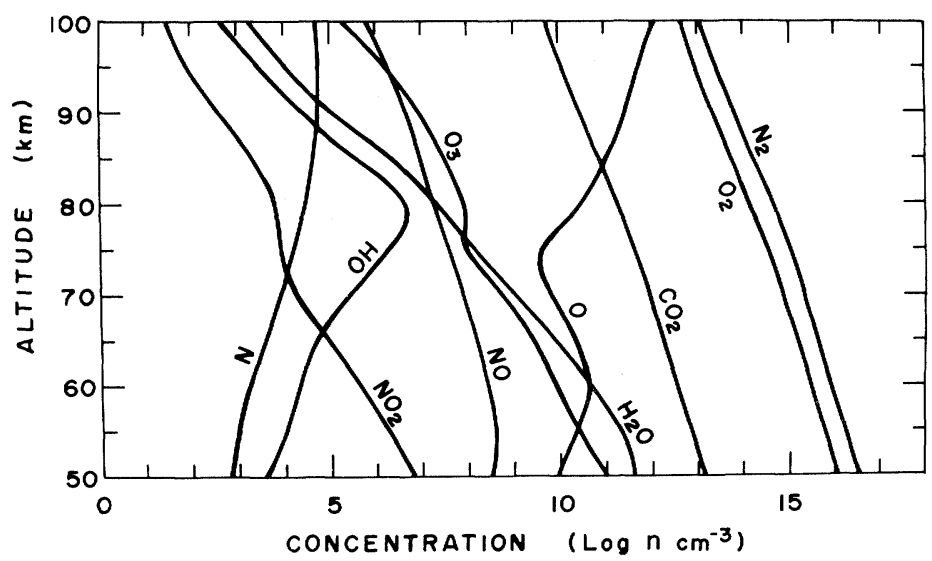

Fig. 1 Assumed distributions of the atmospheric constituents considered in this paper. 
detail elsewhere. It is noted here that a change in the atomic oxygen concentration may lead to a considerable change in the ion composition.

In order to calculate the ion composition, the ionization processes are considered first. All of the constituents in the region below $100 \mathrm{~km}$ are subjected to the ionization due to the incidence of solar X-ray in the wavelength range from $1 \mathrm{~A}$ to about $10 \mathrm{~A}$ and due to the impact of cosmic rays. In addition, $\mathrm{O}_{2}$ and $\mathrm{NO}$ are ionized by the absorption of solar Lyman $\beta$ and Lyman $\alpha$, respectively. The profile of the ionization rate of $\mathrm{O}_{2}$ shown in Fig. 2 is based on the result given by BOURDEAU et al. (1966). As for the NO ionization, this paper employs the intermediate curve given by AIKIN et al. (1964) which is small by an order of magnitude as compared with the curve calculated by REID (1970). The production rate of ionization by the impact of cosmic rays was calculated by WEBBER (1962), and this paper adopts his result for a solar minimum condition at lower latitudes. The production rate of the ionization by cosmic rays for each of the constituents is assumed to be proportional to the abundance of the constituents at a level concerned. The ionization of $\mathrm{O}_{3}, \mathrm{OH}$, and $\mathrm{NO}_{2}$ are ignored in this paper.

Electrons created through the primary ionization processes are followed by recombination with positive ions or by attachment to neutral particles. Negative and positive ions produced are subjected to ionic recombination or neutralization processes and to charge transfer reactions. All of the processes concerned are given in the Appendix together with the rate coefficients. In consequence, the thirteen species of positive ions and the seven species of negative ions are considered in this paper. Water cluster

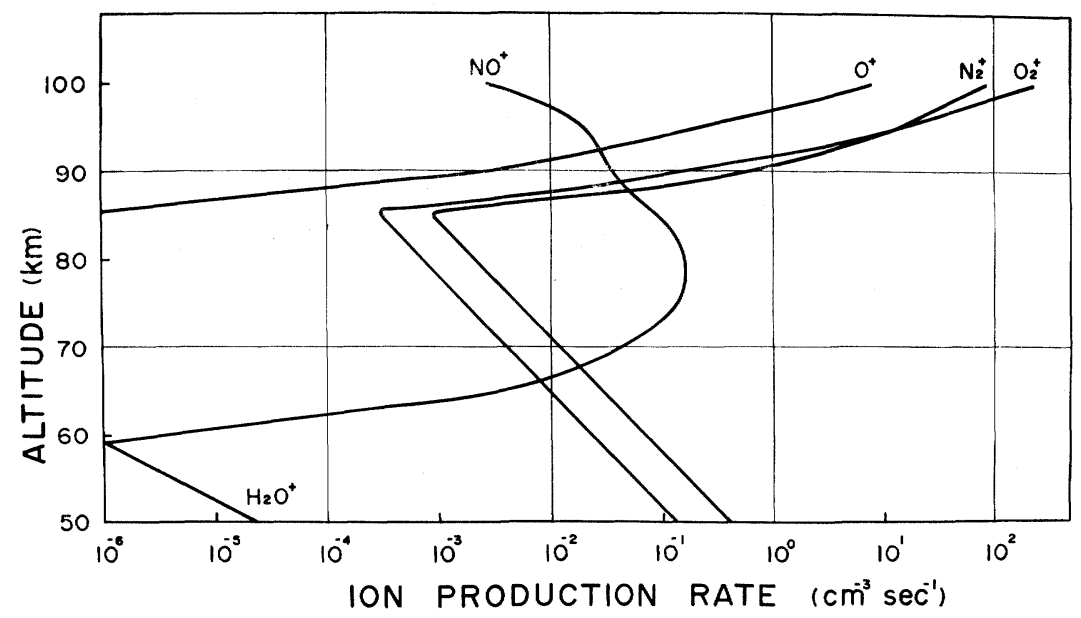

Fig. 2 Assumed profiles of the production rate of ionization for each of the constituents. 

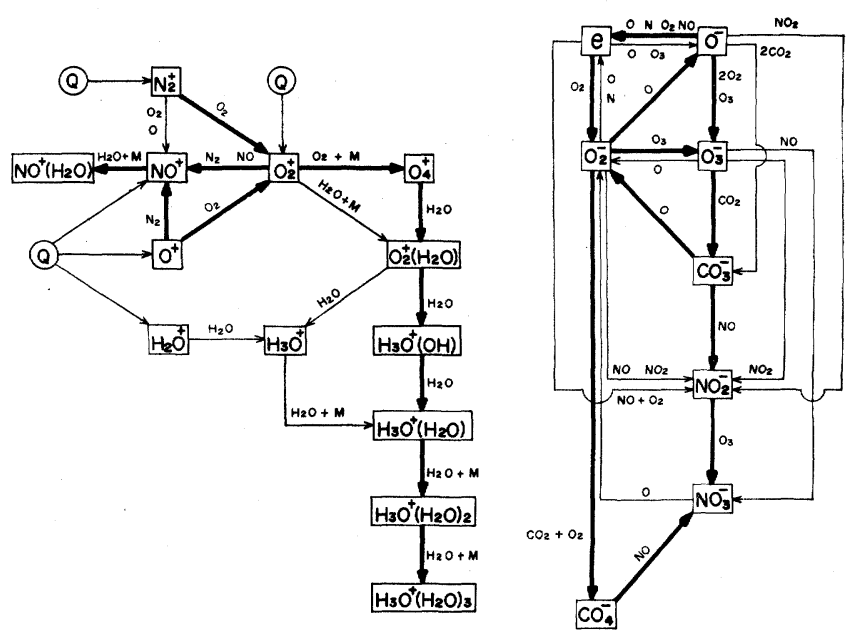

Fig. 3 The sequences of charge transfer leading to the formation of various kinds of ions. The primary ionization processes are indicated by " $Q$ ", and the elements involved in the reactions are shown along the corresponding lines.

negative ions such as $\mathrm{NO}_{3}^{-}\left(\mathrm{H}_{2} \mathrm{O}\right)_{n}$ may possibly be formed, but are not taken into account in this paper.

The sequences of the positive- and negative-ion formation through the ionization and charge transfer processes are illustrated in Fig. 3. The molecules involved in each of the reactions are indicated along the corresponding line. The processes of essential importance at the central altitude $(75 \mathrm{~km}$ ) in the $D$ region are shown by heavy lines. Equating the loss terms to the production terms for each of the species, one obtains the 21 expressions for the densities of ions and electrons in the equilibrium condition as follows :

$$
[\mathrm{e}]=\frac{\sum_{x} q_{x}+\left[\mathrm{O}^{-}\right]\left(\gamma_{1}[\mathrm{O}]+\gamma_{2}\left[\mathrm{~N}_{2}\right]+\gamma_{5}\left[\mathrm{O}_{2}\right]+\gamma_{6}[\mathrm{NO}]\right)+\left[\mathrm{O}_{2}^{-}\right]\left(\gamma_{3}[\mathrm{~N}]+\gamma_{4}[\mathrm{O}]\right)+\sum_{j}\left(\mu_{j} n_{j}^{-}\right)}{\sum_{i}\left(\alpha_{e i} n_{i}^{+}\right)+\beta_{1}[\mathrm{O}]+\beta_{2}\left[\mathrm{O}_{2}\right]+\beta_{3}\left[\mathrm{O}_{3}\right]+\beta_{4}\left[\mathrm{O}_{2}\right]^{2}+\beta_{5}\left[\mathrm{O}_{2}\right]\left[\mathrm{N}_{2}\right]+\beta_{6}\left[\mathrm{O}_{2}\right][\mathrm{NO}]},
$$

$$
\begin{aligned}
& {\left[\mathrm{O}^{+}\right]=\frac{q_{\mathrm{O}}}{k_{1}\left[\mathrm{O}_{2}\right]+k_{2}\left[\mathrm{~N}_{2}\right]+\sum_{j}\left(\alpha_{1 j} n_{j}^{-}\right)},} \\
& {\left[\mathrm{O}_{2}^{+}\right]=\frac{q_{\mathrm{O}_{2}}+\left[\mathrm{O}_{2}\right]\left\{k_{1}\left[\mathrm{O}^{+}\right]+k_{6}\left[\mathrm{~N}_{2}^{+}\right]\right\}}{k_{3}\left[\mathrm{~N}_{2}\right]+k_{4}[\mathrm{NO}]+[\mathrm{M}]\left\{k_{8}\left[\mathrm{H}_{2} \mathrm{O}\right]+k_{9}\left[\mathrm{O}_{2}\right]\right\}+\alpha_{2}[\mathrm{e}]+\alpha_{14}\left[\mathrm{O}^{-}\right]+\sum_{j}\left(\alpha_{2 j} n_{j}^{-}\right)},}
\end{aligned}
$$

$$
\left[\mathrm{N}_{2}^{+}\right]=\frac{q_{\mathrm{N}_{2}}}{\left(k_{5}+k_{6}\right)\left[\mathrm{O}_{2}\right]+k_{7}[\mathrm{O}]+\alpha_{2}[\mathrm{e}]+\sum_{j}\left(\alpha_{3 j} n_{j}^{-}\right)},
$$




$$
\begin{aligned}
& {\left[\mathrm{NO}^{+}\right]=\frac{q_{\mathrm{NO}}+k_{2}\left[\mathrm{~N}_{2}\right]\left[\mathrm{O}^{+}\right]+\left[\mathrm{O}_{2}^{+}\right]\left\{k_{3}\left[\mathrm{~N}_{2}\right]+k_{4}[\mathrm{NO}]\right\}+\left[\mathrm{N}_{2}^{+}\right]\left\{k_{5}\left[\mathrm{O}_{2}\right]+k_{7}[\mathrm{O}]\right\}}{k_{18}[\mathrm{M}]\left[\mathrm{H}_{2} \mathrm{O}\right]+\alpha_{3}[\mathrm{e}]+\sum_{j}\left(\alpha_{4 j} n_{j}^{-}\right)}} \\
& {\left[\mathrm{H}_{2} \mathrm{O}^{+}\right]=\frac{q_{\mathrm{H}_{2} \mathrm{O}}}{k_{14}\left[\mathrm{H}_{2} \mathrm{O}\right]+\alpha_{5}[\mathrm{e}]+\sum_{j}\left(\alpha_{5 j} n_{j}^{-}\right)},} \\
& {\left[\mathrm{O}_{4}^{+}\right]=\frac{k_{9}[\mathrm{M}]\left[\mathrm{O}_{2}\right]\left[\mathrm{O}_{2}^{+}\right]}{k_{10}\left[\mathrm{H}_{2} \mathrm{O}\right]+\alpha_{4}[\mathrm{e}]+\sum_{j}\left(\alpha_{6 j} n_{j}^{-}\right)}} \\
& {\left[\mathrm{O}_{2}^{+}\left(\mathrm{H}_{2} \mathrm{O}\right)\right]=\frac{k_{8}[\mathrm{M}]\left[\mathrm{H}_{2} \mathrm{O}\right]\left[\mathrm{O}_{2}^{+}\right]+k_{10}\left[\mathrm{H}_{2} \mathrm{O}\right]\left[\mathrm{O}_{4}^{+}\right]}{\left(k_{11}+k_{12}\right)\left[\mathrm{H}_{2} \mathrm{O}\right]+\alpha_{7}[\mathrm{e}]+\sum_{j}\left(\alpha_{7 j} n_{j}^{-}\right)}} \\
& {\left[\mathrm{H}_{3} \mathrm{O}^{+}\right]=\frac{\left[\mathrm{H}_{2} \mathrm{O}\right]\left\{k_{11}\left[\mathrm{O}_{2}^{+}\left(\mathrm{H}_{2} \mathrm{O}\right)\right]+k_{14}\left[\mathrm{H}_{2} \mathrm{O}^{+}\right]\right\}}{k_{15}[\mathrm{M}]\left[\mathrm{H}_{2} \mathrm{O}\right]+\alpha_{6}[\mathrm{e}]+\sum_{j}\left(\alpha_{8 j} n_{j}^{-}\right)}} \\
& {\left[\mathrm{H}_{3} \mathrm{O}^{+}(\mathrm{OH})\right]=\frac{k_{12}\left[\mathrm{H}_{2} \mathrm{O}\right]\left[\mathrm{O}_{2}^{+}\left(\mathrm{H}_{2} \mathrm{O}\right)\right]}{k_{13}\left[\mathrm{H}_{2} \mathrm{O}\right]+\alpha_{8}[\mathrm{e}]+\sum_{j}\left(\alpha_{9 j} n_{j}^{-}\right)}} \\
& {\left[\mathrm{H}_{3} \mathrm{O}^{+}\left(\mathrm{H}_{2} \mathrm{O}\right)\right]=\frac{\left[\mathrm{H}_{2} \mathrm{O}\right]\left\{k_{13}\left[\mathrm{H}_{3} \mathrm{O}^{+}(\mathrm{OH})\right]+k_{15}[\mathrm{M}]\left[\mathrm{H}_{3} \mathrm{O}^{+}\right]\right\}}{k_{16}[\mathrm{M}]\left[\mathrm{H}_{2} \mathrm{O}\right]+\alpha_{9}[\mathrm{e}]+\sum_{j}\left(\alpha_{10 j} n_{j}^{-}\right)}} \\
& {\left[\mathrm{H}_{3} \mathrm{O}^{+}\left(\mathrm{H}_{2} \mathrm{O}_{2}\right)\right]=\frac{k_{16}[\mathrm{M}]\left[\mathrm{H}_{2} \mathrm{O}\right]\left[\mathrm{H}_{3} \mathrm{O}^{+}\left(\mathrm{H}_{2} \mathrm{O}\right)\right]}{k_{17}[\mathrm{M}]\left[\mathrm{H}_{2} \mathrm{O}\right]+\alpha_{10}[\mathrm{e}]+\sum_{j}\left(\alpha_{11 j} n_{j}^{-}\right)}} \\
& {\left[\mathrm{H}_{3} \mathrm{O}^{+}\left(\mathrm{H}_{2} \mathrm{O}\right)_{3}\right]=\frac{k_{17}[\mathrm{M}]\left[\mathrm{H}_{2} \mathrm{O}\right]\left[\mathrm{H}_{3} \mathrm{O}^{+}\left(\mathrm{H}_{2} \mathrm{O}\right)_{2}\right]}{\alpha_{11}[\mathrm{e}]+\sum_{j}\left(\alpha_{12 j} n_{j}^{-}\right)}} \\
& {\left[\mathrm{NO}^{+}\left(\mathrm{H}_{2} \mathrm{O}\right)\right]=\frac{k_{18}[\mathrm{M}]\left[\mathrm{H}_{2} \mathrm{O}\right]\left[\mathrm{NO}^{+}\right]}{\alpha_{12}[\mathrm{e}]+\sum_{j}\left(\alpha_{13} n_{j}^{-}\right)},}
\end{aligned}
$$$$
\left[\mathrm{O}^{-}\right]=\frac{[\mathrm{e}]\left\{\beta_{1}[\mathrm{O}]+\beta_{3}\left[\mathrm{O}_{3}\right]+\right.}{\sum_{i}\left(\alpha_{i 1} n_{i}^{+}\right)+k_{19}\left[\mathrm{NO}_{2}\right]+k_{20}\left[\mathrm{O}_{3}\right]+k_{34}\left[\mathrm{O}_{2}\right]^{2}+k_{35}\left[\mathrm{CO}_{2}\right]^{2}+}
$$$$
\frac{+k_{21}[\mathrm{O}]\left[\mathrm{O}_{2}^{-}\right]}{+\gamma_{1}[\mathrm{O}]+\gamma_{2}[\mathrm{~N}]+\gamma_{5}\left[\mathrm{O}_{2}\right]+\gamma_{6}[\mathrm{NO}]+\mu_{1}}
$$$$
\left[\mathrm{O}_{2}^{-}\right]=\frac{[\mathrm{e}]\left[\mathrm{O}_{2}\right]\left\{\beta_{2}+\beta_{4}\left[\mathrm{O}_{2}\right]+\beta_{5}\left[\mathrm{~N}_{2}\right]\right\}+k_{28}[\mathrm{O}]\left[\mathrm{O}_{3}^{-}\right]+}{\sum_{i}\left(\alpha_{i 2} n_{i}^{+}\right)+k_{21}[\mathrm{O}]+k_{22}\left[\mathrm{NO}_{2}\right]+k_{23}[\mathrm{NO}]+k_{24}\left[\mathrm{O}_{3}\right]+}
$$$$
\frac{+k_{30}[\mathrm{O}]\left[\mathrm{CO}_{3}^{-}\right]+k_{33}[\mathrm{O}]\left[\mathrm{NO}_{3}^{-}\right]}{+k_{36}\left[\mathrm{O}_{2}\right]\left[\mathrm{CO}_{2}\right]+\gamma_{3}[\mathrm{~N}]+\gamma_{4}[\mathrm{O}]+\mu_{2}}
$$$$
\left[\mathrm{O}_{3}^{-}\right]=\frac{k_{20}\left[\mathrm{O}_{3}\right]\left[\mathrm{O}^{-}\right]+k_{24}\left[\mathrm{O}_{3}\right]\left[\mathrm{O}_{2}^{-}\right]+k_{34}\left[\mathrm{O}_{2}\right]^{2}\left[\mathrm{O}^{-}\right]}{\sum_{i}\left(\alpha_{i 3} n_{i}^{+}\right)+k_{25}\left[\mathrm{CO}_{2}\right]+k_{26}[\mathrm{NO}]+k_{27}\left[\mathrm{NO}_{2}\right]+k_{28}[\mathrm{O}]+\mu_{3}},
$$$$
\left[\mathrm{CO}_{3}^{-}\right]=\frac{k_{25}\left[\mathrm{CO}_{2}\right]\left[\mathrm{O}_{3}^{-}\right]+k_{35}\left[\mathrm{CO}_{2}\right]^{2}[\mathrm{O}]}{\sum_{i}\left(\alpha_{i 4} n_{i}^{+}\right)+k_{29}[\mathrm{NO}]+k_{30}[\mathrm{O}]+\mu_{4}},
$$$$
\left[\mathrm{CO}_{4}^{-}\right]=\frac{k_{36}\left[\mathrm{O}_{2}\right]\left[\mathrm{CO}_{2}\right]\left[\mathrm{O}_{2}^{-}\right]}{\sum_{i}\left(\alpha_{i 5} n_{i}^{+}\right)+k_{31}[\mathrm{NO}]+\mu_{7}},
$$ 


$$
\begin{aligned}
{\left[\mathrm{NO}_{2}^{-}\right]=} & \frac{\beta_{6}[\mathrm{NO}]\left[\mathrm{O}_{2}\right][\mathrm{e}]+k_{19}\left[\mathrm{NO}_{2}\right]\left[\mathrm{O}^{-}\right]+k_{22}\left[\mathrm{NO}_{2}\right]\left[\mathrm{O}_{2}^{-}\right]+k_{23}[\mathrm{NO}]\left[\mathrm{O}_{2}^{-}\right]}{\sum_{i}\left(\alpha_{i 6} n_{i}^{+}\right)+k_{32}\left[\mathrm{O}_{3}\right]} \\
& \frac{+k_{27}\left[\mathrm{NO}_{2}\right]\left[\mathrm{O}_{3}^{-}\right]+k_{29}\left[\mathrm{NO}^{2}\right]\left[\mathrm{CO}_{3}^{-}\right]}{+\mu_{5}},
\end{aligned}
$$

and

$$
\left[\mathrm{NO}_{3}^{-}\right]=\frac{k_{32}\left[\mathrm{O}_{3}\right]\left[\mathrm{NO}_{2}^{-}\right]+k_{26}[\mathrm{NO}]\left[\mathrm{O}_{3}^{-}\right]+k_{3}[\mathrm{NO}]\left[\mathrm{CO}_{4}^{-}\right]}{\sum_{i}\left(\alpha_{i 7} n_{i}^{+}\right)+k_{33}[\mathrm{O}]+\mu_{6}},
$$

where

$[\mathrm{M}]=\sum_{x} n_{x}$

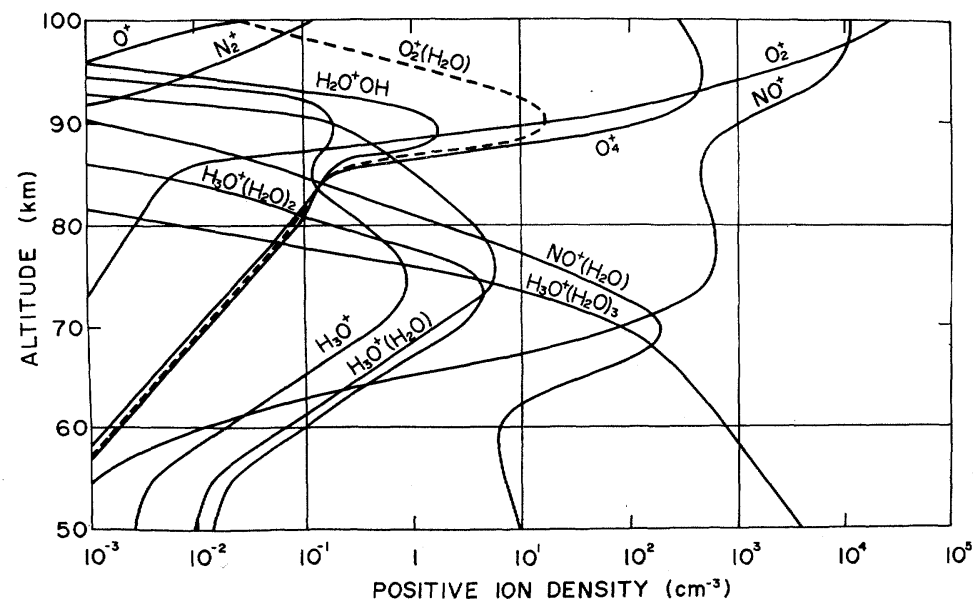

Fig. 4 Calculated distributions of the positive ion densities.

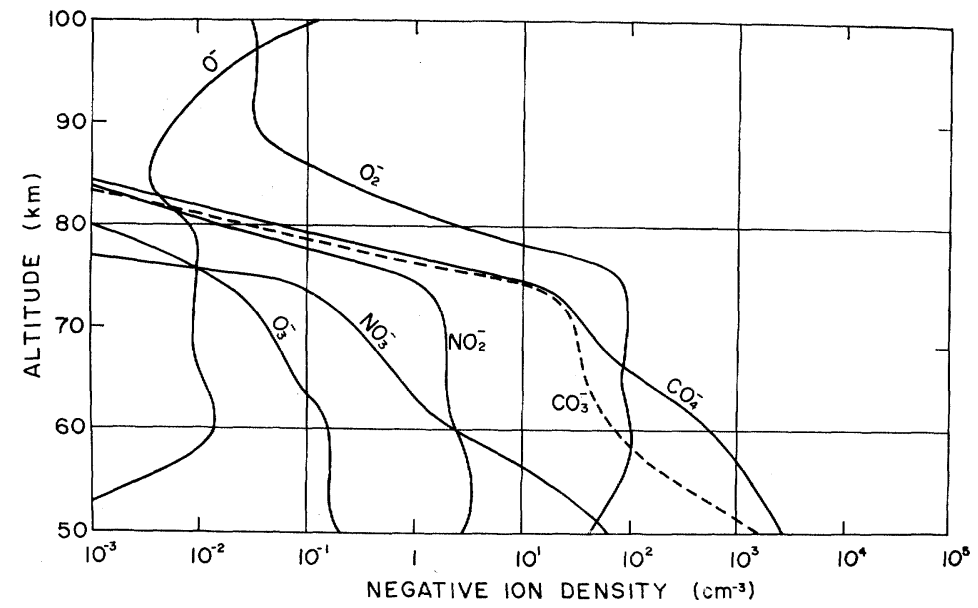

Fig. 5 Calculated distributions of the negative ion densities. 


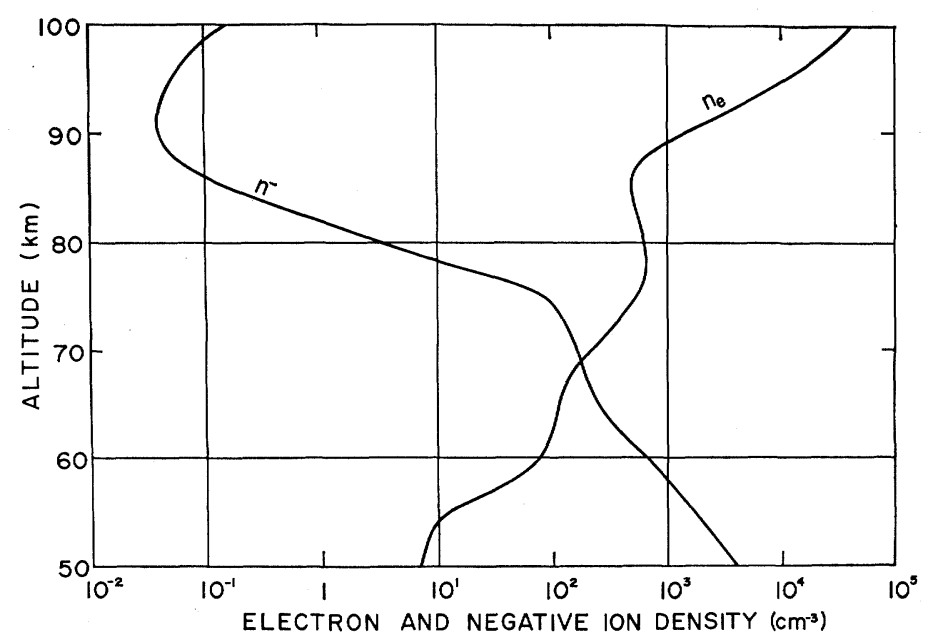

Fig. 6 Calculated distributions of the electron density and the total density of negative ions.

The charge neutrality requires that

$$
\sum_{i} n_{i}^{+}=[\mathrm{e}]+\sum_{j} n_{j}^{-}
$$

In order to obtain a set of the numerical results satisfying the simultaneous Eqs. (13) through (34), a trial-and-error method is adopted. With the use of an electronic computer, calculations are proceeded until the condition of the charge neutrality is satisfied within an error of $0.1 \%$. The results are shown in Fig. 4 for the height distributions of positive ions and in Fig. 5 for those of negative ions. The major positive ions are shown to be $\mathrm{NO}^{+}, \mathrm{NO}^{+}\left(\mathrm{H}_{2} \mathrm{O}\right)$, and $\mathrm{H}_{3} \mathrm{O}^{+}\left(\mathrm{H}_{2} \mathrm{O}\right)_{3}$, especially in the lower $D$ region. The sharp maxima at about the $90 \mathrm{~km}$-level in the $\mathrm{H}_{3} \mathrm{O}^{+}, \mathrm{O}_{2}^{+}\left(\mathrm{H}_{2} \mathrm{O}\right)$, and $\mathrm{H}_{3} \mathrm{O}^{+}\left(\mathrm{H}_{2} \mathrm{O}\right)$ distributions are resulted mainly from the charge transfer from $\mathrm{O}_{2}^{+}$to $\mathrm{O}_{4}^{+}$and, in turn, to $\mathrm{O}_{2}^{+}\left(\mathrm{H}_{2} \mathrm{O}\right), \mathrm{H}_{3} \mathrm{O}^{+}(\mathrm{OH})$, and $\mathrm{H}_{3} \mathrm{O}^{+}\left(\mathrm{H}_{2} \mathrm{O}\right)$, whereas the broad maxima in the lower region $(60-70 \mathrm{~km})$ are due to the charge transfer from $\mathrm{H}_{2} \mathrm{O}^{+}$leading to $\mathrm{H}_{3} \mathrm{O}^{+}\left(\mathrm{H}_{2} \mathrm{O}\right)_{3}$ through $\mathrm{H}_{3} \mathrm{O}^{+}$. In Fig. 5, it is seen that $\mathrm{O}_{2}^{-}, \mathrm{CO}_{3}^{-}, \mathrm{CO}_{4}^{-}$, and $\mathrm{NO}_{3}^{-}$are the dominating negative ions in the lower part of the region. The electron density and the total of the negative ion densities are shown in Fig. 6. From the figure, the negative ion-electron ratio is unity at about the $70 \mathrm{~km}$-level above which the ratio is considerably low as compared with the estimate by ADAMS and MEGILL (1967).

\section{Ion Composition and Resultant Loss Rate of Electrons}

Based on the results shown in the preceding section, the percentage composition is given as a function of altitude in Fig. 7 for positive ions 


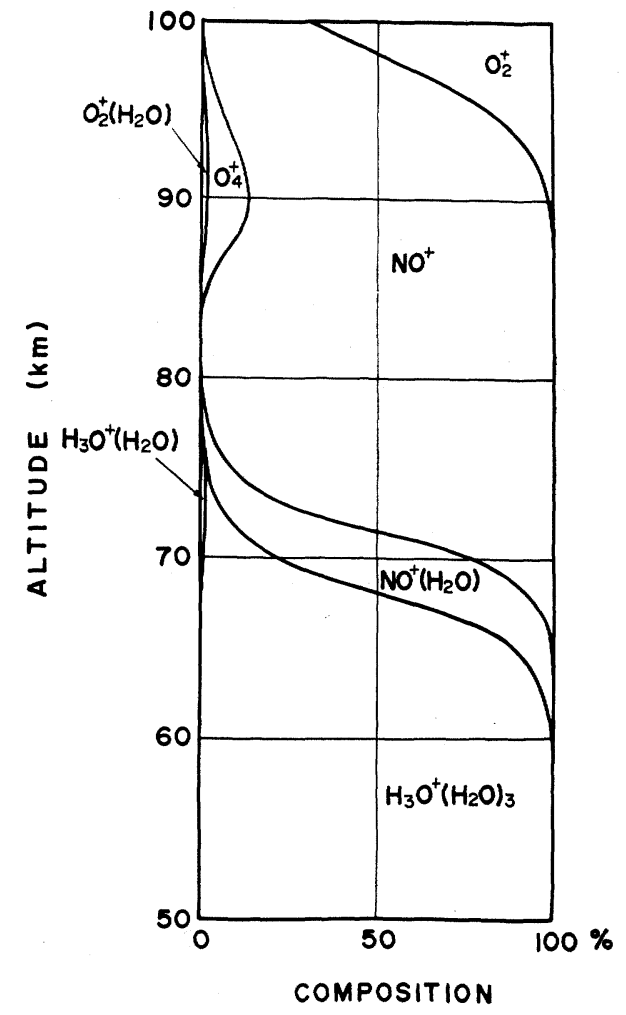

Fig. 7 Calculated percentage composition of the major positive ions shown as a function of altitude.

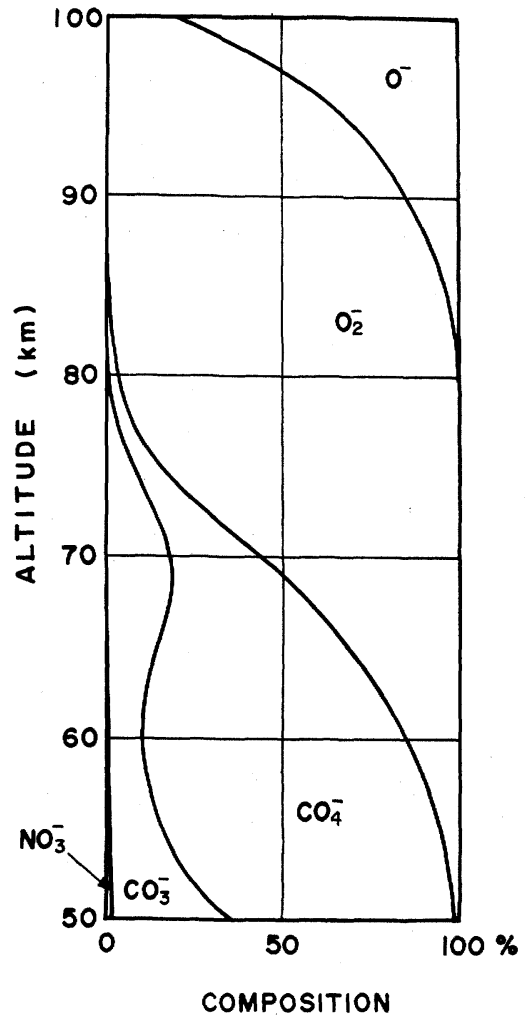

Fig. 8 Calculated percentage composition of the major negative ions shown as a function of altitude.

and in Fig. 8 for negative ions. The negative ion-electron ratio is calculated from the results given in Fig. 6 and is shown in Fig. 9. Then, according to Eqs. (11) and (12), the effective recombination coefficient, $\alpha^{\prime}$, and the effective loss rate for electrons, $\phi$, are calculated and the results are shown in Fig. 9. For comparison, the loss rates estimated by ADAMS and MASLey (1965) and by PARThasarathy and RAI (1966) from PCA events, by WHITTEN et al. (1965) from the artifitial disturbance induced by a nuclear detonation, and by SMITH et al. (1965) from a solar eclipse effect are also shown in the figure. It is surprising that the theoretical result obtained in this paper is seen to be in good agreement with these observational results deduced from the events in which the ionizing sources are certainly quite different from that, assumed in this paper.

It is noted here that, according to our numerical experiment, a change in the composition of minor constituents leads to only a slight change in the effective loss rate. 


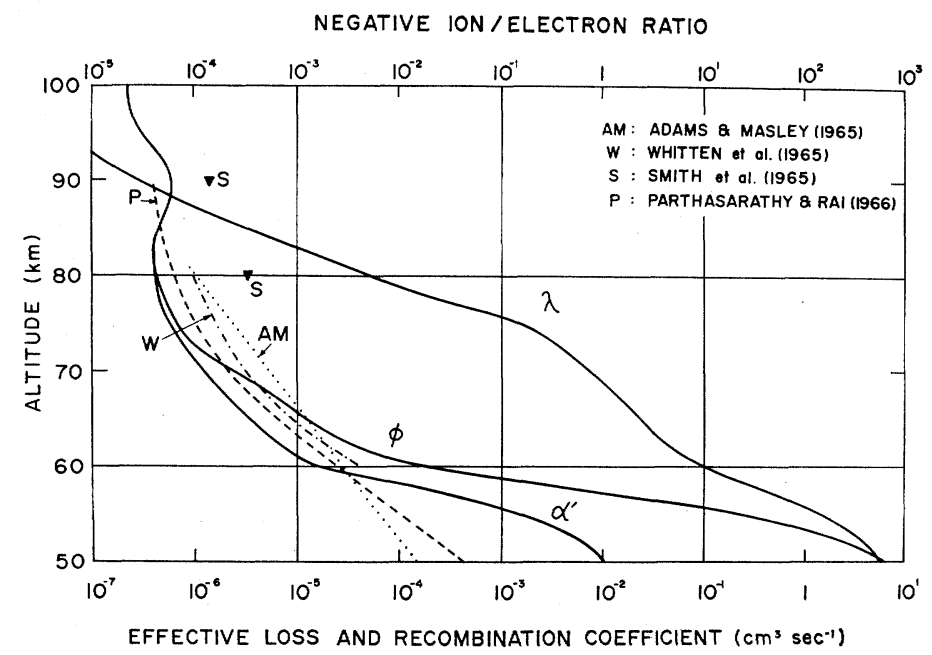

Fig. 9 The negative ion-electron density ratio, $\lambda$, the effective recombination coefficient, $\alpha^{\prime}$, and the effective loss rate, $\phi$, shown as a function of altitude. Some observed $\phi$ 's are also presented for comparison.

\section{Discussions and Concluding Remarks}

First, a discussion is given of the theoretical result for the positive ion distribution in the $D$ region. For comparison, the resuls of the mass spectroscopic measurements by NARCISI and BAILEY (1965) of positive ions are reproduced in Fig. 10. In general, the dominance of the water cluster ions in the lower ionosphere may be understood as the consequence of the chemical processes considered in this paper. However, the sharp

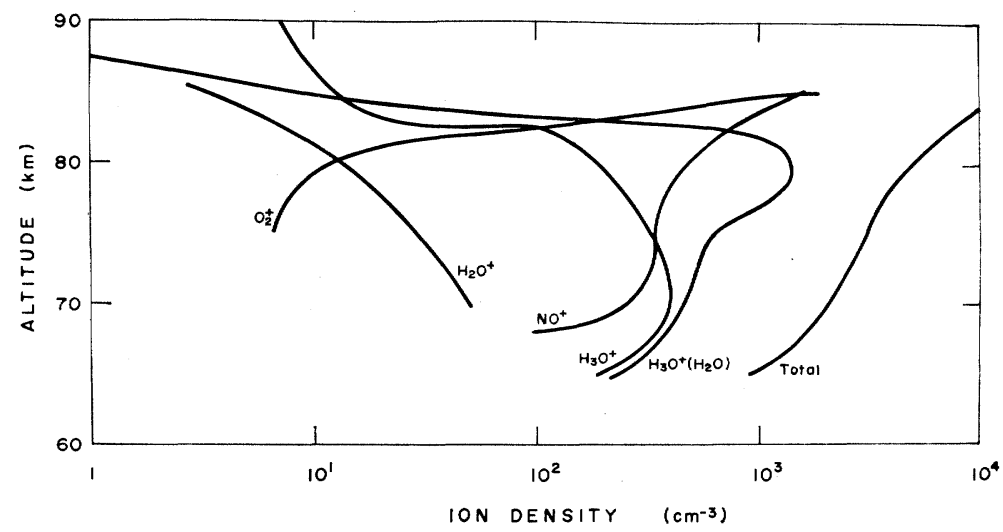

Fig. 10 The distributions of positive ions measured by means of a rocketborne mass spectrometer. (After NARCISI and BAILEY, 1965) 
maxima at the $90 \mathrm{~km}$-level in the density profiles of $\mathrm{O}_{2}^{+}\left(\mathrm{H}_{2} \mathrm{O}\right), \mathrm{H}_{3} \mathrm{O}^{+}(\mathrm{OH})$, and $\mathrm{H}_{3} \mathrm{O}^{+}\left(\mathrm{H}_{2} \mathrm{O}\right)$ appeared in the theoretical result were not detected in the experiment by Narcisi and Bailey. If the observational result represents a normal condition of the positive ion distribution, the assumptions of the composition of the minor constituents and of the rate coefficient for some of the chemical prosesses considered in this paper should be revised so as to remove the sharp peaks at the $90 \mathrm{~km}$-level in the profiles. As mentioned in the previous section, these ions at these altitudes are produced mainly through the processes,

$$
\begin{aligned}
& \mathrm{O}_{2}^{+}+\mathrm{O}_{2}+\mathrm{M} \longrightarrow \mathrm{O}_{4}^{+}+\mathrm{M}, \\
& \mathrm{O}_{4}^{+}+\mathrm{H}_{2} \mathrm{O} \longrightarrow \mathrm{O}_{2}^{+}\left(\mathrm{H}_{2} \mathrm{O}\right)+\mathrm{O}_{2}, \\
& \mathrm{O}_{2}^{+}\left(\mathrm{H}_{2} \mathrm{O}\right)+\mathrm{H}_{2} \mathrm{O} \longrightarrow \mathrm{H}_{3} \mathrm{O}^{+}(\mathrm{OH})+\mathrm{O}_{2},
\end{aligned}
$$

and

$$
\mathrm{H}_{3} \mathrm{O}^{+}(\mathrm{OH})+\mathrm{H}_{2} \mathrm{O} \longrightarrow \mathrm{H}_{3} \mathrm{O}^{+}\left(\mathrm{H}_{2} \mathrm{O}\right)+\mathrm{OH} \text {. }
$$

Thus, it is obvious that the densities of $\mathrm{O}_{2}^{+}\left(\mathrm{H}_{2} \mathrm{O}\right), \mathrm{H}_{3} \mathrm{O}^{+}(\mathrm{OH})$, and $\mathrm{H}_{3} \mathrm{O}^{+}\left(\mathrm{H}_{2} \mathrm{O}\right)$ can be depressed by reducing the amount of water vapor or by slowing the reaction rates concerned. Taking into account the photodissociation effect, the amount of water vapor is assumed to be about $3.3 \times 10^{-6}$ of the total density at $60 \mathrm{~km}$, about $3.3 \times 10^{-7}$ at $75 \mathrm{~km}$, and about $1.0 \times 10^{-9}$ at $90 \mathrm{~km}$ in the present calculation. Therefore, the experimental result may suggest that the dissociation degree of $\mathrm{H}_{2} \mathrm{O}$ is much more pronounced than is assumed in this paper. As for the reaction rate for the process, $\mathrm{O}_{2}^{+}+\mathrm{O}_{2}+\mathrm{M} \longrightarrow \mathrm{O}_{4}^{+}+\mathrm{M}$, this paper adopts the value of $1.0 \times 10^{-29} \mathrm{~cm}^{6} \mathrm{sec}^{-1}$. If this rate can be reduced by two orders of magnitude, the sharp maxima under consideration may possibly disappear. Although $\mathrm{O}_{4}^{+}$is out of the range of the mass spectrometer employed by NARCISI and BAILEY (1965), measurements of the positive ion composition including heavier ions will be quite useful for better understanding of the reaction rates.

A further discussion requires the consideration of the effect of eddy diffusion which is ignored in this paper. Therefore, in this paper the stress is placed rather on the relation between the effective recombination coefficient and the ion composition, and the conclusions are drawn as follows :

(1) The effective recombination coefficient for electrons in the $D$ region can be expressed in the same form, $\alpha^{\prime}=\left\langle\alpha_{e}\right\rangle+\lambda\left\langle\alpha_{\text {in }}\right\rangle$, as has been employed in the upper regions, regardless of the large variety of ion species. Here, $\left\langle\alpha_{e}\right\rangle$ is the weighted mean of the electronic recombination coefficients according to the positive ion composition, while $\left\langle\alpha_{\text {ion }}\right\rangle$ is the ionic recombination coefficient averaged with weights proportional to the relative abundances of the positive and negative ions being present at a level concerned. 
(2) The effective loss rate of electrons is given by $(1+\lambda) \alpha^{\prime}$.

(3) Neglecting the effect of diffusion, a tentative calculation is made on the composition of positive and negative ions. It is shown that major ions in the upper $D$ region are $\mathrm{O}_{2}^{+}, \mathrm{O}_{4}^{+}, \mathrm{NO}^{+}, \mathrm{O}^{-}$, and $\mathrm{O}_{2}^{-}$, while the lower region is characterized by the dominance of $\mathrm{NO}^{+}\left(\mathrm{H}_{2} \mathrm{O}\right), \mathrm{H}_{3} \mathrm{O}^{+}\left(\mathrm{H}_{2} \mathrm{O}\right)_{3}, \mathrm{O}_{2}^{-}, \mathrm{CO}_{3}^{-}, \mathrm{CO}_{4}^{-}$, and $\mathrm{NO}_{3}^{-}$.

(4) The negative ion-electron ratio increases with decreasing altitude, being about $10^{-2}$ at $80 \mathrm{~km}$, about 1 at $70 \mathrm{~km}$, and $10^{2}$ at $55 \mathrm{~km}$.

(5) The effective loss rate estimated theoretically in this paper on the basis of the ion composition in chemical equilibrium is found to be in fairly good agreement with the results derived from the observations of PCA's, SID's, and solar eclipse events.

(6) The distribution of each of the positive ion densities does not fit satisfactorily to the observational results. Although the theoretical result can be modified by changing the assumed composition of the minor constituents and by changing some of the reaction rates, dynamical effects such as atmospheric circulation and eddy diffusion should be taken into account for essential understanding of the problem.

\section{Reference}

ADAMS, G.W. and A.J. MASLEY, Production rates and electron densities in the lower ionosphere due to solar cosmic rays, J. Atmos. Terr. Phys., 27, 289-298, 1965.

ADAMS, G.W. and L.R. MEGILL, A two ion D-region model for polar cap absorption events, Planet. Space Sci., 15, 1111-1130, 1967.

AIKIN, A.C., J.A. KANE, and J. Troim, Some results of rocket experiments in the quiet $D$ region, J. Geophys. Res., 69, 4621-4628, 1964.

BARTH, C.A., Rocket measurement of nitric oxide in the upper atmosphere, Planet. Space Sci., 14, 623-630, 1966.

Biondi, M.A., Electron-ion and ion-ion recombination, Ann. Géophys., 20, 34-46, 1964.

BourdeAU, R.E., A.C. AIKIN, and J.L. Donley, Lower ionosphere at solar minimum, $J$. Geophys. Res., 71, 727-740, 1966.

BRANSCOMB, L.M., A review of photodetachment and related negative ion processes relevant to aeronomy, Ann. Géophys., 20, 88-105, 1964.

Branscomb, L.M., D.S. Burch, S.J. Smith, and S. Geltman, Photodetachment cross section and the electron affinity of atomic oxygen, Phys. Rev., 111, 504-513, 1958.

Chanin, L.M., A.V. Phelps, and M.A. Biondi, Measurement of the attachment of slow electrons in oxygen, Phys. Rev. Lett., 2, 344-346, 1959.

FEHSENFELD, F.C. and E.E. FERGUSON, Further laboratory measurements of negative reactions of atmospheric interest, Planet. Space Sci., 16, 701-702, 1968.

Fehsenfeld, F.C. and E.E. Ferguson, Origin of water cluster ions in the $D$ region, $J$. Geophys. Res., 74, 2217-2222, 1969.

FeHsenfeld, F.C., E.E. Ferguson, and D.K. BoHME, Additional flowing afterglow measurement of negative ion reactions of D-region interest, Planet. Space Sci., 17, 1759$1762,1969$.

Fehsenfeld, F.C., E.E. Ferguson, and A.L. Schmeltekopf, Thermal-Energy Associative- 
Detachment reactions of negative ions, J. Chem. Phys., 45, 1844-1845, 1966.

FeHSEnfeld, F.C., P.D. Goldan, A.L. Schmeltekopf, and E.E. Ferguson, Laboratory measurement of the rate of the reaction $\mathrm{Q}^{+}+\mathrm{O}_{2} \rightarrow \mathrm{O}_{2}^{+}+\mathrm{O}$ at thermal energy, Planet. Space Sci., 6, 579-582, 1965.

Fehsenfeld, F.C., A.L. Schmeltekopf, H.I. Schiff, and E.E. Ferguson, Laboratory measurements of negative ion reactions of atmospheric interest, Planet. Space Sci., 15, 373-379, 1967.

Ferguson, E.E. and F.C. FeHSENFELD, Water vapor ion cluster concentrations in the $D$ region, J. Geophys. Res., 74, 5743-5751, 1969.

Ferguson, E.E., F.C. Fehsenfeld, P.D. Goldan, and A.L. Schmeltekopf, Positive ionneutral reactions in the ionosphere, J. Geophys. Res., 70, 4323-4329, 1965.

Ferguson, E.E., F.C. Fehsenfeld, and A.L. Schmeltekopf, Laboratory measurements of ionospheric ion-molecule reactions, Space Res., VII-1, 135-139, North-Holland Pub. Co., 1967.

GunTon, R.C. and T.M. SHAw, Electron-ion recombination in nitric oxide in the temperature range 196 to $358^{\circ} \mathrm{K}$, Phys. Rev., 140A, 756-763, 1965.

HesstVedt, E. and U.B. JANSon, On the effect of vertical eddy transport on the distribution of neutral nitrogen compounds in the D-region, Aeronomy Rep., 32, Univ. Illinois, 190-194, 1969.

HunT, B.G., Photochemistry of ozone in a moist atmosphere, J. Geophys. Res., 71, 1385-1398, 1966.

KASNER, W.H. and M.A. BIONDI, Temperature dependence of the electron $\mathrm{O}_{2}{ }^{+}$Ion recombination coefficient, Phys. Rev., 174, 139-144, 1968.

KenEsheA, T.J., Theoretical variations of minor constituents during an eclipse, Aeronomy Rep., 32, Univ. Illinois, 400-413, 1969.

MAHAN, B.J. and J.C. Person, Gaseous ion recombination rates, J. Chem. Phys., 40, 392401, 1964.

Mechtly, E.A. and L.G. Smith, Growth of D-region at sunrise, J. Atmos. Terr. Phys., 30, 363-369, 1968.

MoruzZI, J.L. and A.V. Phelps, Survey of negative-ion-molecule reactions in $\mathrm{O}_{2}, \mathrm{CO}_{2}, \mathrm{H}_{2} \mathrm{O}$, CO, and mixtures of these gases at high pressures, J. Chem. Phys., 45, 4617-4627, 1966.

NARCISI, R.S. and A.D. BAILEY, Mass spectrometric measurements of positive ions at altitudes from 64 to 112 kilometers, J. Geophys. Res., 70, 3687-3700, 1965.

PACK, J.L. and A.V. PHELPS, Electron attachment and detachment. I. Pure $\mathrm{O}_{2}$ at low energy, J. Chem. Phys., 44, 1870-1883, 1966.

PARTHASARATHY, R. and D.B. RAI, Effective recombination coefficient in the $D$ region, Radio Sci., 1, 1397-1400, 1966.

REID, G.C., Production and loss of electrons in the quiet daytime $D$ region of the ionosphere, J. Geophys. Res., 75, 2551-2562, 1970.

RUTHERFORD, J.A. and B.R. TURNER, The production of $\mathrm{NO}_{2}{ }^{-}$by electron transfer from $\mathrm{O}^{-}, \mathrm{O}_{2}{ }^{-}, \mathrm{O}_{3}^{-}$, and $\mathrm{OH}^{-}$to $\mathrm{NO}_{2}, J$. Geophys. Res., 72, 3795-3800, 1967.

SECHRIST, C.F., Interpretation of pre-sunrise electron densities and negative ions in the $D$ region, J. Atmos. Terr. Phys., 30, 371-389, 1968.

SHIMAZAKI, T. and A.R. LAIRD, A model calculation of the diurnal variation in minor neutral constituents in the mesosphere and lower thermosphere including transport effects, J. Geophys. Res., 75, 3221-3235, 1970.

Smith, L.G., Ozone concentration at sunrise by absorption spectroscopy, Aeronomy Rep., 32, 207-209, Univ. Illinois, 1969.

Smith, L.G., C.A. Accardo, L.H. Weeks and P.J. McKinnon, Measurements in the ionosphere during the solar eclipse of 20 July 1963, J. Atmos. Terr. Phys., 27, 803-829, 1965. 
WARNECK, P., Laboratory rate coefficients for positive ion-neutral reactions in the ionosphere (Letters), J. Geophys. Res., 72, 1651-1653, 1967.

WEBBER, W., The production of free electrons in the ionospheric $D$ layer by solar and galactic cosmic rays and the resultant absorption of radio waves, J. Geophys. Res., 67, 5091-5106, 1962.

WhitTen, R.C., I.G. Poppoff, R.S. Edmonds, and W.W. BeRning, Effective recombination coefficients in the lower ionosphere, J. Geophys. Res., 70, 1737-1742, 1965.

Woo, S.B., L.M. BRANSCOMB, and E.C. BEATY, Sunlight photodetachment rate of ground state $\mathrm{O}_{2}^{-}$, J. Geophys. Res., 74, 2933-2940, 1969.

\section{Appendix}

The reactions considered in this paper are listed below together with the rate coefficients in units of $\mathrm{cm}^{3} \mathrm{sec}^{-1}$ for two-body processes, $\mathrm{cm}^{6} \mathrm{sec}^{-1}$ for three-body processes, and of $\sec ^{-1}$ /ion for photodetachment processes. Electronic recombination processes

\section{Attachment processes}

$$
\begin{aligned}
& \mathrm{e}+\mathrm{O} \rightarrow \mathrm{O}^{-}+h \nu \\
& \mathrm{e}+\mathrm{O}_{2} \longrightarrow \mathrm{O}_{2}{ }^{-}+h \nu \\
& \mathrm{e}+\mathrm{O}_{3} \rightarrow \mathrm{O}^{-}+\mathrm{O}_{2} \\
& \mathrm{e}+\mathrm{O}_{2}+\mathrm{O}_{2} \rightarrow \mathrm{O}_{2}^{-}+\mathrm{O}_{2} \\
& \mathrm{e}+\mathrm{N}_{2}+\mathrm{O}_{2} \rightarrow \mathrm{O}_{2}^{-}+\mathrm{N}_{2} \\
& \mathrm{e}+\mathrm{NO}+\mathrm{O}_{2} \rightarrow \mathrm{NO}_{2}^{-}+\mathrm{O}
\end{aligned}
$$

Rate Coefficient

$\alpha_{5}=1.0 \times 10^{-7}$

$\alpha_{6}=1.0 \times 10^{-6}$

$\alpha_{7}=1.0 \times 10^{-6}$

$\alpha_{8}=1.0 \times 10^{-6}$

$\alpha_{9}=1.0 \times 10^{-6}$

$\alpha_{10}=1.0 \times 10^{-6}$

$\alpha_{11}=1.0 \times 10^{-6}$

$\alpha_{12}=1.0 \times 10^{-6}$

$\beta_{1}=1.3 \times 10^{-15}$

$\beta_{2}=9.0 \times 10^{-17}$

$\beta_{4}=2.0 \times 10^{-30}$

$\beta_{5}=1.0 \times 10^{-31}$

\section{Reference}

KASNER and BIONDI (1968) BIONDI (1964)

GUNTON and SHAW (1965)

KASNER and BIONDI (1968) (assumed)

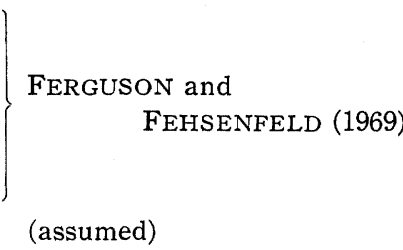

Very slow, and ignored in this paper.

BRANSCOMB et al. (1958)

$\beta_{3}=5.0 \times 10^{-12}$

$\beta_{6}=2.2 \times 10^{-31}$

PACK and PHELPS (1966)

Assumed with reference to

FEHSENFELD and

FERGUSON (1968)

PACK and Phelps (1966)

CHANIN et al. (1959)

GUNTON and SHAW (1965)

Ionic neutralization processes

$\mathrm{O}^{+}+\mathrm{O}^{-} \rightarrow$ neutralization

$\mathrm{O}^{+}+\mathrm{XY}^{-} \rightarrow$ neutralization

$\mathrm{O}_{2}^{+}+\mathrm{O}^{-} \rightarrow$ neutralization

$\mathrm{O}_{2}{ }^{+}+\mathrm{XY}^{-} \rightarrow$ neutralization

$\mathrm{N}_{2}{ }^{+}+\mathrm{XY}^{-} \rightarrow$ neutarlization

$\mathrm{NO}^{+}+\mathrm{XY}^{-} \rightarrow$ neutralization

$$
\begin{aligned}
& \alpha_{13}=5 \times 10^{-8} \\
& \alpha_{14}=5 \times 10^{-8} \\
& \alpha_{15}=2 \times 10^{-7} \\
& \alpha_{16}=2 \times 10^{-7} \\
& \alpha_{17}=2 \times 10^{-7}
\end{aligned}
$$

\author{
Assumed \\ Assumed \\ MAHAN and PERSON (1964)
}


$\mathrm{O}_{4}^{+}+\mathrm{XY}^{-} \rightarrow$ neutralization

$\mathrm{H}_{2} \mathrm{O}^{+}+\mathrm{XY}^{-} \rightarrow$ neutralization

$\mathrm{H}_{3} \mathrm{O}^{+}+\mathrm{XY}^{-} \rightarrow$ neutralization

$\mathrm{O}_{2}{ }^{+}\left(\mathrm{H}_{2} \mathrm{O}\right)+\mathrm{XY}^{-} \rightarrow$ neutralization

$\mathrm{H}_{3} \mathrm{O}^{+}(\mathrm{OH})+\mathrm{XY}^{-} \rightarrow$ neutralization

$\mathrm{H}_{3} \mathrm{O}^{+}\left(\mathrm{H}_{2} \mathrm{O}\right)+\mathrm{XY}^{-} \rightarrow$ neutralization

$\mathrm{H}_{3} \mathrm{O}^{+}\left(\mathrm{H}_{2} \mathrm{O}\right)_{2}+\mathrm{XY}^{-} \rightarrow$ neutralization

$\mathrm{H}_{3} \mathrm{O}^{+}\left(\mathrm{H}_{2} \mathrm{O}\right)_{3}+\mathrm{XY}^{-} \rightarrow$ neutralization

$\mathrm{NO}^{+}\left(\mathrm{H}_{2} \mathrm{O}\right)+\mathrm{XY}^{-} \rightarrow$ neutralization

$\begin{array}{ll}\alpha_{18}=1 \times 10^{-7} & \text { Assumed } \\ \alpha_{19}=1 \times 10^{-7} & \text { Assumed } \\ \alpha_{20}=1 \times 10^{-7} & \text { Assumed } \\ \alpha_{21}=1 \times 10^{-7} & \text { Assumed } \\ \alpha_{22}=1 \times 10^{-7} & \text { Assumed } \\ \alpha_{23}=1 \times 10^{-7} & \text { Assumed } \\ \alpha_{24}=1 \times 10^{-7} & \text { Assumed } \\ \alpha_{25}=1 \times 10^{-7} & \text { Assumed } \\ \alpha_{26}=1 \times 10^{-7} & \text { Assumed }\end{array}$

Charge transfer processes for positive ions

$\begin{array}{ll}\mathrm{O}^{+}+\mathrm{O}_{2} \rightarrow \mathrm{O}_{2}{ }^{+}+\mathrm{O} & k_{1}=4.0 \times 10^{-11} \\ \mathrm{O}^{+}+\mathrm{N}_{2} \rightarrow \mathrm{NO}^{+}+\mathrm{N} & k_{2}=3.0 \times 10^{-12} \\ \mathrm{O}_{2}{ }^{+}+\mathrm{N}_{2} \rightarrow \mathrm{NO}^{+}+\mathrm{NO} & k_{3}=3.0 \times 10^{-16} \\ \mathrm{O}_{2}{ }^{+}+\mathrm{NO} \rightarrow \mathrm{NO}^{+}+\mathrm{O}_{2} & k_{4}=7.7 \times 10^{-10} \\ \mathrm{~N}_{2}{ }^{+}+\mathrm{O}_{2} \rightarrow \mathrm{NO}^{+}+\mathrm{NO} & k_{5}=2.0 \times 10^{-14} \\ \mathrm{~N}_{2}{ }^{+}+\mathrm{O}_{2} \rightarrow \mathrm{O}_{2}{ }^{+}+\mathrm{N}_{2} & k_{6}=1.0 \times 10^{-10} \\ \mathrm{~N}_{2}{ }^{+}+\mathrm{O} \rightarrow \mathrm{NO}^{+}+\mathrm{N} & k_{7}=2.5 \times 10^{-10} \\ \mathrm{O}_{2}{ }^{+}+\mathrm{H}_{2} \mathrm{O}+\mathrm{M} \rightarrow \mathrm{O}_{2}{ }^{+}\left(\mathrm{H}_{2} \mathrm{O}\right)+\mathrm{M} & k_{8}=1.0 \times 10^{-27} \\ \mathrm{O}_{2}{ }^{+}+\mathrm{O}_{2}+\mathrm{M} \rightarrow \mathrm{O}_{4}+\mathrm{M} & k_{9}=1.0 \times 10^{-29} \\ \mathrm{O}_{4}{ }^{+}+\mathrm{H}_{2} \mathrm{O} \rightarrow \mathrm{O}_{2}{ }^{+}\left(\mathrm{H}_{2} \mathrm{O}\right)+\mathrm{O}_{2} & k_{10}=1.5 \times 10^{-9} \\ \mathrm{O}_{2}{ }^{+}\left(\mathrm{H}_{2} \mathrm{O}\right)+\mathrm{H}_{2} \mathrm{O} \rightarrow \mathrm{H}_{3} \mathrm{O}^{+}+\mathrm{OH}+\mathrm{O}_{2} & k_{11}=1.2 \times 10^{-10} \\ \mathrm{O}_{2}{ }^{+}\left(\mathrm{H}_{2} \mathrm{O}\right)+\mathrm{H}_{2} \mathrm{O} \rightarrow \mathrm{H}_{3} \mathrm{O}^{+}(\mathrm{OH})+\mathrm{O}_{2} & k_{12}=1.2 \times 10^{-9} \\ \mathrm{H}_{3} \mathrm{O}^{+}(\mathrm{OH})+\mathrm{H}_{2} \mathrm{O} \rightarrow \mathrm{H}_{3} \mathrm{O}^{+}\left(\mathrm{H}_{2} \mathrm{O}\right)+\mathrm{OH} & k_{13}=1.2 \times 10^{-9} \\ \mathrm{H}_{2} \mathrm{O}^{+}+\mathrm{H}_{2} \mathrm{O} \rightarrow \mathrm{H}_{3} \mathrm{O}^{+}+\mathrm{OH} & k_{14}=1.0 \times 10^{-9} \\ \mathrm{H}_{3} \mathrm{O}^{+}+\mathrm{H}_{2} \mathrm{O}+\mathrm{M} \rightarrow \mathrm{H}_{3} \mathrm{O}^{+}\left(\mathrm{H}_{2} \mathrm{O}\right)+\mathrm{M} & k_{15}=1.0 \times 10^{-27} \\ \mathrm{H}_{3} \mathrm{O}^{+}\left(\mathrm{H}_{2} \mathrm{O}\right)+\mathrm{H}_{2} \mathrm{O}+\mathrm{M} \rightarrow \mathrm{H}_{3} \mathrm{O}^{+}\left(\mathrm{H}_{2} \mathrm{O}\right)_{2}+\mathrm{M} & k_{16}=3.0 \times 10^{-27} \\ \mathrm{H}_{3} \mathrm{O}^{+}\left(\mathrm{H}_{2} \mathrm{O}\right)_{2}+\mathrm{H}_{2} \mathrm{O}+\mathrm{M} \rightarrow \mathrm{H}_{3} \mathrm{O}^{+}\left(\mathrm{H}_{2} \mathrm{O}\right)_{3}+\mathrm{M} & k_{17}=2.0 \times 10^{-27} \\ \mathrm{NO}^{+}+\mathrm{H}_{2} \mathrm{O}+\mathrm{M} \rightarrow \mathrm{NO}^{+}\left(\mathrm{H}_{2} \mathrm{O}\right)+\mathrm{M} & k_{18}=1.5 \times 10^{-28}\end{array}$

FEHSENFELD et al. (1965)

FEHSENFELD et al. (1967)

BARTH (1966)

WARNECK (1967)

FERGUSON et al. (1965)

FERGUSON and

FEHSENFELD (1969)

FEHSENFELD and

FERGUSON (1969)

FERGUSON and

FEHSENFELD (1969)

FEHSENFELD and

FERGUSON (1969)

\section{Charge transfer processes for negative ions}

$$
\begin{aligned}
& \mathrm{O}^{-}+\mathrm{NO}_{2} \rightarrow \mathrm{O}+\mathrm{NO}_{2}^{-} \\
& \mathrm{O}^{-}+\mathrm{O}_{3} \rightarrow \mathrm{O}+\mathrm{O}_{3}^{-} \\
& \mathrm{O}_{2}{ }^{-}+\mathrm{O} \longrightarrow \mathrm{O}_{2}+\mathrm{O}^{-} \\
& \mathrm{O}_{2}{ }^{-}+\mathrm{NO}_{2} \rightarrow \mathrm{O}_{2}+\mathrm{NO}_{2}{ }^{-} \\
& \mathrm{O}_{2}{ }^{-}+\mathrm{NO} \rightarrow \mathrm{O}+\mathrm{NO}_{2}{ }^{-} \\
& \mathrm{O}_{2}^{-}+\mathrm{O}_{3} \rightarrow \mathrm{O}_{2}+\mathrm{O}_{3}^{-} \\
& \mathrm{O}_{3}{ }^{-}+\mathrm{CO}_{2} \rightarrow \mathrm{CO}_{3}{ }^{-}+\mathrm{O}_{2} \\
& \mathrm{O}_{3}{ }^{-}+\mathrm{NO} \rightarrow \mathrm{NO}_{3}{ }^{-}+\mathrm{O} \\
& \mathrm{O}_{3}{ }^{-}+\mathrm{NO}_{2} \rightarrow \mathrm{O}_{3}+\mathrm{NO}_{2}{ }^{-} \\
& \mathrm{O}_{3}{ }^{-}+\mathrm{O} \rightarrow \mathrm{O}_{2}{ }^{-}+\mathrm{O}_{2} \\
& \mathrm{CO}_{3}{ }^{-}+\mathrm{NO} \rightarrow \mathrm{NO}_{2}{ }^{-}+\mathrm{CO}_{2} \\
& \mathrm{CO}_{3}{ }^{-}+\mathrm{O} \rightarrow \mathrm{O}_{2}{ }^{-}+\mathrm{CO}_{2} \\
& \mathrm{CO}_{4}{ }^{-}+\mathrm{NO} \rightarrow \mathrm{NO}_{3}{ }^{-}+\mathrm{CO}_{2} \\
& \mathrm{NO}_{2}{ }^{-}+\mathrm{O}_{3} \rightarrow \mathrm{NO}_{3}{ }^{-}+\mathrm{O}_{2} \\
& \mathrm{NO}_{3}{ }^{-}+\mathrm{O} \rightarrow \mathrm{O}_{2}{ }^{-}+\mathrm{NO}_{2}
\end{aligned}
$$$$
k_{19}=1.1 \times 10^{-9}
$$$$
k_{20}=7.0 \times 10^{-10}
$$$$
k_{21}=1.0 \times 10^{-11}
$$$$
k_{22}=8.0 \times 10^{-10}
$$

$k_{23}=5.0 \times 10^{-12}$

$k_{24}=3.0 \times 10^{-10}$

$k_{25}=4.0 \times 10^{-10}$

$k_{26}=1.0 \times 10^{-11}$

$k_{27}=7.0 \times 10^{-10}$

$k_{28}=1.4 \times 10^{-10}$

$k_{29}=9.0 \times 10^{-12}$

$k_{30}=8.0 \times 10^{-11}$

$k_{31}=4.8 \times 10^{-11}$

$k_{32}=1.8 \times 10^{-11}$

$k_{33}=8.0 \times 10^{-11}$
RUTHERFORD and TURNER (1967)

FEHSENFELD et al. (1967)

KENESHEA (1969)

FEHSENFELD and FERGUSON (1968)

KenesheA (1969)

FEHSENFELD et al. (1967)

RUTHERFORD and TURNER (1967)

KenesheA (1969)

FEHSENFELD et al. (1967)

FEHSENFELD et al. (1969)

\} KENESHEA (1969) 
$\mathrm{O}^{-}+\mathrm{O}_{2}+\mathrm{O}_{2} \rightarrow \mathrm{O}_{3}^{-}+\mathrm{O}_{2}$

$\mathrm{O}^{-}+\mathrm{CO}_{2}+\mathrm{CO}_{2} \rightarrow \mathrm{CO}_{3}^{-}+\mathrm{CO}_{2}$

$\mathrm{O}_{2}{ }^{-}+\mathrm{CO}_{2}+\mathrm{O}_{2} \rightarrow \mathrm{CO}_{4}{ }^{-}+\mathrm{O}_{2}$

Associative detachment processes

$\mathrm{O}^{-}+\mathrm{O} \rightarrow \mathrm{O}_{2}+\mathrm{e}$

$\mathrm{O}^{-}+\mathrm{N} \rightarrow \mathrm{NO}+\mathrm{e}$

$\mathrm{O}_{2}{ }^{-}+\mathrm{N} \rightarrow \mathrm{NO}_{2}+\mathrm{e}$

$\mathrm{O}_{2}{ }^{-}+\mathrm{O} \rightarrow \mathrm{O}_{3}+\mathrm{e}$

$\mathrm{O}^{-}+\mathrm{O}_{2} \rightarrow \mathrm{O}_{3}+\mathrm{e}$

$\mathrm{O}^{-}+\mathrm{NO} \rightarrow \mathrm{NO}_{2}+\mathrm{e}$

Photodetachment processes

$\mathrm{O}^{-}+h \nu \rightarrow \mathrm{O}+\mathrm{e}$

$\mathrm{O}_{2}{ }^{-}+h \nu \rightarrow \mathrm{O}_{2}+\mathrm{e}$

$\mathrm{O}_{3}^{-}+h \nu \rightarrow \mathrm{O}_{3}+\mathrm{e}$

$\mathrm{CO}_{3}^{-}+h \nu \rightarrow \mathrm{CO}_{3}+\mathrm{e}$

$\mathrm{NO}_{2}{ }^{-}+h \nu \rightarrow \mathrm{NO}_{2}+\mathrm{e}$

$\mathrm{NO}_{3}{ }^{-}+h \nu \rightarrow \mathrm{NO}_{3}+\mathrm{e}$

$\mathrm{CO}_{4}^{-}+h \nu \rightarrow \mathrm{CO}_{4}+\mathrm{e}$ $k_{34}=9.0 \times 10^{-31}(200 / \mathrm{T})$ BRANSCOMB (1964)

$k_{35}=9.0 \times 10^{-29}$

$k_{36}=2.0 \times 10^{-29}$

Moruzzi and Phelps (1966)

$$
\begin{aligned}
& \gamma_{1}=1.9 \times 10^{-10} \\
& \gamma_{2}=2.2 \times 10^{-10} \\
& \gamma_{3}=4.0 \times 10^{-10} \\
& \gamma_{4}=3.3 \times 10^{-10} \\
& \gamma_{5}=1.0 \times 10^{-12} \\
& \gamma_{6}=5.0 \times 10^{-10}
\end{aligned}
$$

FEHSENFELD et al. (1967)

FEHSENFELD et al. (1966)

$\mu_{1}=1.4$

$\mu_{2}=0.3$

$\mu_{3}=0.04$

$\mu_{4}=0.03$

$\mu_{5}=0.02$

$\mu_{6}=0.01$

$\mu_{7}=0.03$

BRANSCOMB et al. (1958)

Woo et al. (1969)

(assumed)

(assumed)

(assumed)

(assumed)

(assumed) 